\author{
N.S. Imanbaev ${ }^{1}$, B.E. Kanguzhin ${ }^{2}$ \\ ${ }^{1}$ Sout Kazakhstan State Pedagogical University, Shymkent, Kazakhstan; \\ ${ }^{2}$ Al-Farabi Kazakh National University, Almaty, Kazakhstan \\ (E-mail: imanbaevnur@mail.ru)
}

\title{
On spectral question of the Cauchy-Riemann operator with homogeneous boundary value conditions
}

\begin{abstract}
In this paper we consider the eigenvalue problem for the Cauchy-Riemann operator with homogeneous Dirichlet type boundary conditions. The statement of the problem is justified to the theorem of M. Otelbaev and A.N. Shynybekov, which implies the correctness of the considered problem. As an example, non-local boundary conditions and Bitsadze-Samarskii type boundary conditions are given. It is taken into account that the above spectral problem for a differential Cauchy-Riemann operator with homogeneous boundary conditions of the Dirichlet type type is reduced to a singular integral, also reduces to a linear integral equation of the second kind with a continuous kernel. And it is also taken into account that the index of the singular integral equation is zero and the Noetherian condition is obtain. It is proved that the considered spectral problem does not have eigenvalues, that is, for any complex ?, has only the zero solution and thus the Cauchy-Riemann spectral problem is a Volterra problem.
\end{abstract}

Keywords: Cauchy-Riemann operator, Dirichlet type problem, spectral parameter, resolvent set, residues, kernel, homogeneous boundary conditions, Volterra property, Noetherian, Fredholm equation.

\section{Introduction}

In the functional space $C(|z| \leq 1)$ we consider an operator $K$, generated by the differential Cauchy-Riemann operation

$$
K \omega(z)=\frac{\partial \omega(z)}{\partial \bar{z}}
$$

where $z=x+i y, \bar{z}=x-i y, \frac{\partial}{\partial \bar{z}}=\frac{1}{2}\left(\frac{\partial}{\partial x}+i \frac{\partial}{\partial y}\right)$ on the set

$$
D(K) \subset\left\{\omega(x) \in C(|z| \leq 1), \frac{\partial \omega}{\partial \bar{z}} \in C(|z|<1)\right\} .
$$

We assume that the operator $K$ has a non-empty resolvent set $\rho(K)$. Not begging for generality, we assume that

$$
0 \in \rho(K),
$$

i.e. there is a bounded operator $K^{-1}$. In [1] the set of the operators $\{K\}$ with the property $(1)$ has been described:

Theorem 1. [1]. For every linear operator $K$ with the property (1) there exists a bounded operator $G$, which carries continuous functions in the circle $|z| \leq 1$ into holomorphic functions for which imaginary parts are equal to zero when $z=0$, and also the bounded functional $S(f)$ on the set of continuous functions in the circle $|z| \leq 1$ that uniquely determine domain of the operator $\mathrm{K}$ by the formula:

$$
\begin{gathered}
D(K)=\left\{\omega(z) \in C(|z| \leq 1), \frac{\partial \omega}{\partial \bar{z}} \in C(|z|<1), \operatorname{Re} \omega(z)=\operatorname{Re} G\left(\frac{\partial \omega}{\partial \bar{z}}\right),|z|=1 ;\right. \\
\left.\operatorname{Im} \omega(0)=\operatorname{Im} S\left(\frac{\partial \omega}{\partial \bar{z}}\right),|z|=0\right\} .
\end{gathered}
$$

Inversely, the pair of $G$ and $S$ determines, for which (1) is true.

It is known in $[2 ; 151]$, that the boundary value problem:

$$
\frac{\partial \omega}{\partial \bar{z}}=f(z),|z|<1 ;
$$




$$
\begin{gathered}
\left.\operatorname{Re} \omega(z)\right|_{|z|=1}=g(z) ; \\
\operatorname{Im} \omega(0)=C,
\end{gathered}
$$

has a unique solution $\omega(z)$ at any selection

$$
f(z) \in C(|z|<1), g(z) \in C(|z|=1), C \in R .
$$

Moreover, this solution is obtained by the Schwartz's formula [2] (in the multidimensional case by the Poisson formula):

$$
\omega(z)=\frac{1}{2 \pi i} \oint_{|t|=1} g(z) \frac{t+z}{t-z} \cdot \frac{d t}{t}+i C+L_{\Phi}^{-1} f(z),
$$

where

$$
\omega_{\Phi}(z)=L_{\Phi}^{-1} f(z)
$$

is a solution of the homogenous boundary value problem for the non-homogenous equation:

$$
\frac{\partial \omega_{\Phi}(z)}{\partial \bar{z}}=f(z),|z|<1,
$$

with the homogenous boundary value conditions:

$$
\left.\operatorname{Re} \omega_{\Phi}(z)\right|_{|z|=1}=0, \quad \operatorname{Im} \omega_{\Phi}(0)=0 .
$$

Let the operator be given by the Cauchy-Riemann relation and the condition (1) holds, that means existence of the inverse operator $K^{-1}$, it implies, that the operator equation $K \omega(z)=f(z)$ has the unique solution $\omega(z)=K^{-1} f(z)$.

Denote the real part of the solution $\omega(z)$ on the circle $|z|=1$ by $g(z)$, and the imaginary part of the solution $\omega(z)$ when $z=0$ by $C$.

In [1] as specific boundary value conditions it is chosen the boundary pair:

$$
\begin{gathered}
(G f)(z)=\frac{1}{2 \pi i} \oint_{|t|=1} \frac{f(t)}{t-z} d t \\
S(f)=\frac{1}{2 \pi i} \oint_{|t|=1} \frac{f(t)}{t} d t .
\end{gathered}
$$

The corresponding eigenvalue problem to this boundary pair has the following form:

$$
\begin{gathered}
\frac{\partial \omega}{\partial \bar{z}}=\lambda \omega(z),|z|<1 \\
\operatorname{Re} \omega(z)=\operatorname{Re} \frac{1}{2 \pi i} \oint_{|t|=1} \frac{\lambda \omega(t)}{t-z} d t, \quad|z|=1 \\
\operatorname{Im} \omega(0)=\operatorname{Im} \frac{1}{2 \pi i} \oint_{|t|=1} \frac{\lambda \omega(t)}{t} d t .
\end{gathered}
$$

For this problem in [3] for the spectral parameter $\lambda$ conditions have been obtained for which the problem is Noetherian in the corresponding function space and is reduced to a linear integral Fredholm equation of the second kind with a continuous kernel. Moreover, formulas, characterizing the approximate structure of solution of the boundary-value problem with shift, have been obtained. The paper [4] is devoted to study of spectrum of elliptic operators. In the general case, the spectrum of an elliptic operator is essentially determined by spectral properties of boundary operator. However, identification dependence of the spectrum of the operator K in initial terms of boundary conditions represents an actual (unresolved) problem. From the general results, such facts are not traced; therefore it is necessary to involve deeper methods, related to specifics of the specific boundary conditions. 


\section{Formulation of the problem}

In [1] along with nonlocal boundary-value conditions, as specific boundary value conditions the BitsadzeSamarskii type boundary conditions, that is, the problem «with shift in interior of the domain» as well as the Dirichlet problem type homogeneous boundary value conditions are chosen, that is,

$$
\begin{gathered}
\left.(G f)(z)\right|_{|z|=1}=0 ; \\
\left.S(f)\right|_{z=0}=0 .
\end{gathered}
$$

Then the spectral problem has the form:

$$
\begin{gathered}
\frac{\partial \omega(z)}{\partial \bar{z}}=\lambda \cdot \omega(z),|z|<1 \\
\operatorname{Re} \omega(z)=0, \quad|z|=1 \\
\operatorname{Im} \omega(0)=0, \quad z=0,
\end{gathered}
$$

where complex $\lambda$ is a spectral parameter, which is reduced to singular integral equation with continuous kernel, and the index is calculated, the condition for the Noetherian is established in $[5,6]$.

This case will be the subject of our research in this paper.

Description of general regular boundary value problems for the differential Cauchy-Riemann expression was developed by J.F. Neiman, M.I. Vishik, A.A. Dezin, in 1982 by M. Otelbayev and A.N. Shynybekov [1].

From another point of view, the problems of solvability and behavior of solution of the boundary value problem for the generalized Cauchy-Riemann equation have been extensively studied in [7-10]. Boundary value problems for the generalized Cauchy-Riemann system with non-smooth coefficients were studied in [11].

Spectral problems with regular but not intensely regular boundary value conditions for the multiple differentiation operator were studied in [12].

\section{Main result of the paper}

Denote general solution of the equation (1) by $\Phi(z)=\omega(z) e^{\lambda \bar{z}}$. Since

$$
\frac{\partial}{\partial \bar{z}}\left(e^{\lambda \bar{z}} \cdot \omega(z)\right)=0
$$

in the circle $|z|<1$ the function $\Phi(z)$ is holomorphic. Consequently, the spectral problem (1a)-(3) has the following form:

$$
\begin{gathered}
\frac{\partial \Phi(z)}{\partial \bar{z}}=0,|z|<1 ; \\
\left.\operatorname{Re}\left(e^{\lambda \bar{z}} \cdot \Phi(z)\right)\right|_{|z|=1}=0 ; \\
\operatorname{Im} \Phi(0)=0 .
\end{gathered}
$$

Rewrite the real part of the complex number (5) in the form of a half-sum of the complex number and its conjugate, then we get to the relation when $|z|=1$, with considering $z \cdot \bar{z}=1$ :

$$
e^{\lambda \bar{z}} \cdot \Phi(z)+e^{\lambda \bar{z}} \cdot \Phi\left(\frac{1}{z}\right)=0
$$

Introduce the function:

$$
\begin{gathered}
\widetilde{\Phi(z)}=\Phi(z),|z|<1 ; \\
\widetilde{\Phi(z)}=\Phi\left(\frac{1}{z}\right),|z|>1 .
\end{gathered}
$$

It follows that $\Phi(z)=\overline{\Phi\left(\frac{1}{z}\right)}$ when $|z|=1$. Then along the unit circle $|z|=1$ we have $e^{\lambda \bar{z}} \widetilde{\Phi_{+}(z)}+e^{\lambda \bar{z}} \widetilde{\Phi_{-}(z)}=0$. 

where

Solution has the following form $[2 ; 147]: \widetilde{\Phi(z)}=e^{\Gamma(z)}$,

$$
\Gamma(z)=-\frac{1}{2 \pi i} \oint_{|t|=1} \frac{\bar{\lambda} t-\lambda \bar{t}}{t-z} d t
$$

When $|z|=1$ check the condition $\Phi(z)=\overline{\Phi\left(\frac{1}{z}\right)}$.

As a result, we get:

$$
\Gamma(z)=\overline{\Gamma\left(\frac{1}{z}\right)}=\frac{1}{2 \pi i} \oint_{|t|=1} \frac{\bar{\lambda} t-\lambda \bar{t}}{t-z} d t=-\frac{1}{2 \pi i} \oint_{|t|=1} \frac{\bar{\lambda} t-\lambda \bar{t}}{t-\frac{1}{z}} \overline{d t} .
$$

Due to $t \cdot \bar{t}=1, z \cdot \bar{z}=1$, we consider the expression when $|t|=1$ and $|z|=1$ :

$$
\frac{\lambda \bar{t}-\bar{\lambda} t}{\bar{t}-\frac{1}{z}}=\frac{\lambda \bar{t}-\bar{\lambda} t}{\frac{1}{t}-z}=\frac{\bar{\lambda} t-\lambda \bar{t}}{1-z t} \cdot t, \overline{d t}=d \bar{t}=d\left(\frac{1}{t}\right)=-\frac{d t}{t^{2}} .
$$

Hence we have

$$
\frac{1}{2 \pi i} \oint_{|t|=1}(\bar{\lambda} t-\lambda \bar{t}) \frac{d t}{t-z}=\frac{1}{2 \pi i} \oint_{|t|=1} \frac{\bar{\lambda} t-\lambda \bar{t}}{1-z t} \frac{d t}{t}
$$

Due to the obvious equality, were write the last integral in the form:

$$
\bar{\lambda} \frac{1}{2 \pi i} \oint_{|t|=1}\left(\frac{t}{t-z}-\frac{1}{1-z t}\right) d t=\lambda \frac{1}{2 \pi i} \oint_{|t|=1}\left(\frac{1}{t(t-z)}-\frac{1}{(1-z t) t^{2}}\right) d t .
$$

By the Deduction Theorem [13] we have that

$$
\bar{\lambda} \cdot\left(z-\lim _{t \rightarrow z} \frac{t-z}{1-z t}\right)=\lambda \cdot\left(\frac{1}{-z}+\frac{1}{z}-\lim _{t \rightarrow z} \frac{t-z}{(1-z t) t^{2}}-\lim _{t \rightarrow 0} \frac{d}{d t}\left(\frac{t^{2}}{(1-z t) t^{2}}\right)\right)
$$

and also

$$
\bar{\lambda} \cdot\left(z-\lim _{t \rightarrow z} \frac{1}{-z}\right)=\lambda \cdot\left(-\frac{1}{z^{2}}\left(-\frac{1}{z}\right)-z\right)
$$

It yields that

$$
\bar{\lambda} \cdot\left(z+\frac{1}{z}\right)=\lambda \cdot\left(z-\frac{1}{z^{3}}\right)=0
$$

that is

$$
\bar{\lambda} \cdot\left(\frac{z^{2}+1}{z}\right)+\lambda \cdot\left(\frac{z^{4}-1}{z^{3}}\right)=0
$$

The last equality is reduced to

$$
\bar{\lambda}+\lambda \cdot\left(\frac{z^{2}-1}{z^{2}}\right)=0 .
$$

Hence, inside the unit circle $|z|=1$ we get $z^{2} \bar{\lambda}+\lambda z^{2}-\lambda=0$.

Taking derivative by $\varphi$ in the polar coordinates, we have:

$$
\frac{\partial}{\partial \varphi} \mid e^{2 i \varphi} \bar{\lambda}+\lambda e^{2 i \varphi}-\lambda=0 .
$$

Then the following equation is true:

$$
2 z \bar{\lambda}=-\lambda 2 z
$$

As a result we receive:

$$
\bar{\lambda}+\lambda=0 .
$$


From this case it is not hard to establish that when $\lambda=0$ condition $z^{2}(-\lambda)+\lambda z^{2}=\lambda$ holds. Thus, it is proved

Theorem 2. The spectral problem (1a)-(3) does not have eigenvalues, that is, for any complex $\lambda$, the spectral problem (1a)-(3) has only the zero solution.

Remark. The spectral problem (1a)-(3) turned out to be a Volterra problem.

In conclusion, the authors express their gratitude to Professor Sh. A. Alimov for attention to the paper. The article was written with the support of the state grant «The Best Teacher of the University - 2017» of the Ministry of Education and Science of the Republic of Kazakhstan.

\section{References}

1 Отелбаев М. О корректных задачах типа Бицадзе-Самарского / М. Отелбаев, А.Н. Шыныбеков // Докл. АН СССР. - 1982. - Т. 265. - № 4. - С. 815-819.

2 Мусхелишвили Н.И. Сингулярные интегральные уравнения / Н.И. Мусхелишвили. - М.: Наука, 1968. $-511 \mathrm{c.}$

3 Иманбаев Н.С. Задача о собственных значениях дифференциального оператора Коши-Римана с нелокальными краевыми условиями / Н.С.Иманбаев // Вестн. Самар. гос. техн. ун-та. Сер. физикоматематические науки. - 2014. - № 1(34). - С. 25-36.

4 Михайлец В.А. Спектральные задачи с общими краевыми условиями: автореф. дис. ... д-ра физ.-мат. наук: 01.01.02 - Дифференциальные уравнения, динамические системы и оптимальное управление; 01.01.01 - Вещественный, комплексный и функциональный анализ / В.А. Михайлец. - Киев, 1989. $-29 \mathrm{c}$.

5 Amanzholova A.B. On an inhomogeneous boundary value problem with shift into the region for the Cauchy-Riemann equations with spectral parameter / A.B. Amanzholova, N.S. Imanbaev, A.D. Niyazymbetov // International Journal of Pure and Applied Mathematics. - 2014. - Vol. 93. - No. 3. P. 449-461.

6 Иманбаев Н.С. О задаче на собственные значения оператора Коши-Римана с однородными краевыми условиями типа задачи Дирихле / Н.С. Иманбаев // Известия НАН PК. Сер. физикоматематическая. - 2015. - № 2(300). - С. 73-77.

7 Бицадзе А.В. О некоторых простейших обобщениях линейных эллиптических краевых задач / А.В. Бицадзе, А.А. Самарский // Докл. АН СССР. - 1969. - Т. 185. - № 4. - С. 739, 740.

8 Нахушев А.М. Задачи со смещением для уравнений в частных производных / А.М. Нахушев. - М.: Наука, 2006. - 287 с.

9 Wang Y. Two Boundary-value Problems for the Cauchy-Riemann Equation in a Sector / Y.Wang // Complex Analysis and Operator Theory. - 2012. - Vol. 6. - No. 6. - P. 1121-1138.

10 Тимофеев А.Ю. Краевая задача для обобщенного уравнения Коши-Римана в пространствах, описываемых модулем непрерывности / А.Ю. Тимофеев // Уфимский математический журнал. -2012. - T. 4. - № 1. - C. 146-152.

11 Оспанов К.Н. Краевые задачи для обобщенной системы Коши-Римана с негладкими коэффициентами / К.Н. Оспанов, М.Отелбаев // Докл. АН СССР. - 1985. - Т. 283. - № 1. - С. 46-49.

12 Imanbaev N.S. On stability of basis property of root vectors system of the Sturm-Liouville operator with an integral perturbation of conditions in nonstrongly regular Samarskii-Ionkin type problems / N.S. Imanbaev // International Journal of Differential Equations. - 2015. Article ID 641481. - 6 p.

13 Титчмарш Е. Теория функций / Е.Титчмарш. - М.: Наука, 1980. - 463 с. 
Н.С. Иманбаев, Б.Е. Кангужин

\title{
Біртекті шеттік шарттармен берілген Коши-Риман операторының спектралдық мәселесі
}

\begin{abstract}
Мақалада Дирихле текті біртекті шеттік шарттармен берілген Коши-Риман операторының меншікті мәндерін зерттеуге арналған есеп қарастырылған. Есептің қисынды қойылуы М. Өтелбаев пен А.Н. Шыныбековтың теоремасына негізделген. Бұл теорема негізінде Коши-Риман операторы үшін бейлокалды шеттік шарттармен берілген және Бицадзе-Самарский текті шеттік шарттармен берілген есептердің мысалдары көрсетілген. Қарастырылып отырған Дирихле текті біртекті шеттік шарттармен берілген Коши-Риман операторының меншікті мәндерін зерттеуге арналған есебінің сингулярлы интегралдық теңдеуге, сонан соң сызықтық интегралдық екінші текті Фредгольм теңдеуіне редукцияланғаны, сондай-ақ сингулярлы интегралдың теңдеудің индексінің нөлге тең болатындығы және нетерлік шарты туралы мәліметтер ескерілген. Авторлар Коши-Риман дифференциалдық операторы үшін қойылған спектралдық есептің меншікті мәндерінің болмайтындығын дәлелдеген, яғни кез келген кешенді $\lambda$ үшін тек қана нөлдік шешімі ғана бар болады.
\end{abstract}

Kiлm сөздер: Коши-Риман операторы, Дирихле тектес есеп, спектралдық параметр, резольвенттік жиын, қалындылар, ядро, біртекті шеттік шарттар, вольтерлік, нетерлі, Фредгольм теңдеуі.

\author{
Н.С. Иманбаев, Б.Е. Кангужин
}

\section{K спектральному вопросу оператора Коши-Римана с однородными краевыми условиями}

В статье рассмотрена задача на собственные значения оператора Коши-Римана с однородными краевыми условиями типа задачи Дирихле. Постановка задачи обоснована к теореме М. Отелбаева и А.Н. Шыныбекова, установлена корректность рассматриваемой задачи, в качестве примера указаны нелокальные краевые условия и краевые условия типа Бицадзе-Самарского. Учитывается, что указанная выше спектральная задача для дифференциального оператора Коши-Римана с однородными краевыми условиями типа задачи Дирихле редуцирована к сингулярному интегральному, затем к линейному интегральному уравнению Фредгольма второго рода с непрерывным ядром. А также учтено, что индекс сингулярного интегрального уравнения равен нулю, и установлено условие нетеровости. Доказано, что рассматриваемая спектральная задача не имеет собственных значений, т.е. при любом комплексном $\lambda$ имеет только нулевое решение.

Ключевые слова: оператор Коши-Римана, задача типа Дирихле, спектральный параметр, резольвентное множество, вычеты, ядро, однородные краевые условия, вольтерровость, нетерово, уравнение Фредгольма.

\section{References}

1 Otelbayev, M., \& Shynybekov, A.N. (1982). O korrektnykh zadachakh tipa Bitsadze-Samarskoho [On correct problems of Bitsadze-Samarskii type]. Doklady AN SSSR - Reports AS USSR, Vol. 265, 815-819 [in Russian].

2 Muskhelishvili, N.I. (1968). Sinhuliarnye intehralnye uravneniia [Singular Integral Equations]. Moscow: Nauka [in Russian].

3 Imanbaev, N.S.(2014). Zadacha o sobstvennykh znacheniiakh differentsialnoho operatora Koshi-Rimana s nelokalnymi usloviiami [Eigenvalues problem of Cauchy-Riemann differential operator with nonlocal boundary value conditions]. Vestnik Samarskoho hosudarstvennoho tekhnicheskoho universiteta. Seriia Fiziko-matematicheskie nauki - Bulletin of the Samara State Technical University. Series Physics and Mathematics, Vol. 1(34), 25-36 [in Russian]. 
4 Mikhailets, V.A. (1989). Spektralnyie zadachi s obshchimi kraievymi usloviiami [Spectral problems with general boundary value conditions]. Extended abstract of doctor's thesis. Kiev [in Russian].

5 Amanzholova, A.B., Imanbaev, N.S., \& Niyazymbetov, A.D. (2014). On an inhomogeneous boundary value problem with shift into the region for the Cauchy-Riemann equations with spectral parameter. International Journal of Pure and Applied Mathematics, Vol. 93 , 449-461.

6 Imanbaev, N.S. (2015). O zadache na sobstvennye znacheniia operatora Koshi-Rimana s odnorodnymi kraevymi usloviiami tipa Dirikhle [On eigenvalue problem for the Cauchy-Riemann operator with homogeneous boundary value conditions of the Dirichlet problem type]. Izvestiia NAN RK. Seriia Fizika $i$ Matematika - Izvestiia NAS RK. Series of Physics and Mathematics, Vol. 2, $73-77$ [in Russian].

7 Bitsadze, A.V., \& Samarskii, A.A. (1969). O nekotorykh prosteyshikh obobshcheniiakh lineinykh ellipticheskikh kraievykh zadach [On some of the simplest generalizations of linear elliptic boundary-value problems]. Doklady AN SSSR - Reports AS USSR, Vol. 185, 739-740 [in Russian].

8 Nakhushev, A.M. (2006). Zadachi so smeshcheniem dlia uravnenii v chastnykh proizvodnykh /Problems with shift for Partial Differential Equations]. Moscow: Nauka [in Russian].

9 Wang, Y., \& Wang, Y. (2012). Two Boundary-value Problems for the Cauchy-Riemann Equation in a Sector. Complex Analysis and Operator Theory, Vol. 6, 6, 1121-1138.

10 Timofeev, A.Yu. (2012). Kraevaia zadacha dlia obobshchennoho uravneniia Koshi-Rimana v prostranstvakh, opisyvaemykh modulem nepreryvnosti [Boundary problem for the generalized Cauchy-Riemann equation in spaces, described by the modulus of continuity]. Ufimskii Matematicheskii Zhurnal - Ufa Mathematical Journal, Vol. 4, 146-152 [in Russian].

11 Ospanov, K.N., \& Otelbaev, M. (1985). Kraevye zadachi dlia obobshchennoi sistemy Koshi-Rimana s nehladkimi koeffitsientami [A generalized Cauchy-Riemann system with nonsmooth coefficients]. Doklady AN SSSR - Reports AS USSR, Vol. 283, 1, 46-49 [in Russian].

12 Imanbaev, N.S. (2015). On stability of basis property of root vectors system of the Sturm-Liouville operator with an integral perturbation of conditions in nonstrongly regular Samarskii-Ionkin type problems. International Journal of Differential Equations, Article ID 641481, 6.

13 Titchmarsh, E. (1980). Teoriia funktsii [Functions Theory]. Moscow: Nauka [in Russian]. 